\title{
İnsan İnsülin Hormonu Öncülerinin Pichia pastoris AOX1 Promotoru Altında Klonlanması, Ekspresyonu ve Biyoreaktörde Üretimi
}

\author{
Aysun TÜRKANOĞLU ÖZÇELIK' ${ }^{* 1}$, Ayşe TORUN², Semiramis YILMAZ², Mehmet İNAN1,2
}

${ }^{1}$ Akdeniz Üniversitesi, Gıda Güvenliği ve Tarımsal Araştırmalar Merkezi, 07058, Antalya, Türkiye

${ }^{2}$ Akdeniz Üniversitesi, Mühendislik Fakültesi, Gıda Mühendisliği Bölümü, 07058, Antalya, Türkiye

(Alınış / Received: 18.01.2018, Kabul / Accepted: 01.10.2018, Online Yayınlanma / Published Online: 19.10.2018)

\section{Anahtar Kelimeler}

İnsülin,

Pichia pastoris,

AOX1 promotoru,

Rekombinant protein
Özet: İnsülin pankreasın beta hücrelerinden üretilen ve vücutta glukoz dengesini sağlayan önemli bir peptit hormondur. Pankreasın yeterli miktarda insülin üretememesi ya da hücrelerin üretilen insüline cevap verememesi sonucu kan glukoz düzeyinin yükselmesiyle diyabet adı verilen metabolik bir hastalık meydana gelir. Günümüzde bu hastalığın tedavisinde insülin hormonu kullanılmaktadır. İnsülin hormonu genetik mühendisliği teknikleri kullanılarak rekombinant olarak üretilen ilk proteindir. İlk olarak Escherichia coli ve Saccharomyces cerevisiae'da üretilmeye başlanmış, ancak son zamanlarda rekombinant insülin üretiminde Pichia pastoris (Komagataella phaffi) 'in kullanımı yaygınlaşmış̦tır. Bu çalışmada, insan insülin hormonu öncülerinin (IP) P. pastoris' in metanol ile indüklenebilir $A O X 1$ promotoru altında üretimini sağlamak amacıyla; bu proteini kodlayan DNA fragmenti transformasyon ve ligasyon gibi moleküler biyoloji teknikleri kullanılarak plazmide aktarılarak istenen proteini kodlayan bir ekspresyon vektörü elde edilmiştir. Ekspresyon vektörünün lityum asetat yöntemiyle yetenekli hale getirilen P. pastoris X33 suşuna elektroporasyonla transferi sağlanmıștır. 5L ölçekli biyoreaktörde yapılan protein ekspresyonu çalışması sonrasında alınan örnekler SDS-PAGE ve ELISA yöntemleriyle analiz edilmiș ve $7.5 \mathrm{mg} / \mathrm{L}$ IP proteini üretildiği tespit edilmiștir.

\section{Cloning, Expression and Production in a Bioreactor of Human Insulin Precursor in Pichia pastoris under AOX1 Promoter}

\section{Keywords}

Insulin,

Pichia pastoris, AOX1 promoter, Recombinant protein

\begin{abstract}
Insulin is a peptide hormone, produced by beta cells of the pancreas, and regulates the glucose homeostasis in the body. Diabetes mellitus is a metabolic disease in which a person has high blood sugar, either because the pancreas does not produce enough insulin, or because cells do not respond to produced insulin. At the present time, insulin is used to treatment of this disease. Insulin hormone is first protein produced recombinantly by using genetic engineering techniques. Firstly, it was produced in E. coli and Saccharomyces cerevisiae, but recently the number of studies that used Pichia pastoris (Komagataella phaffi) in the production of recombinant insulin increase. In this study, in order to produce human insulin hormone precursor (IP) under the inducible AOX1 promoter in $P$. pastoris, an expression vector encoding desired protein was obtained by transferring DNA fragment coding this protein to the plasmid using molecular biology techniques such as transformation and ligation. Expression vector was transferred via electroporation to Pichia pastoris X33 strain which rendered by lithium acetate method. After protein expression study in $5 \mathrm{~L}$ bioreactor, obtained samples were analyzed with SDS-PAGE and ELISA methods and determined 7.5 $\mathrm{mg} / \mathrm{L}$ protein produced.
\end{abstract}




\section{Giriş}

Diyabet (şeker hastalı̆̆ ), popülasyon içinde teşhis edilmiş, bir o kadar da teşhis edilememiş olarak bulunan ve insanlar arasında en yaygın olarak görülen hastalıklardan birisidir. İnsülin hormonunun yokluğu, yetersizliği veya etkisizliği nedeniyle hiperglisemi (yüksek kan şekeri) ile birlikte özel komplikasyonlara yol açan bir hastalıktır [1]. Tedavi edilmediği durumlarda bu hastalığın uzun süreli etkisi çeşitli organ hasarları ve yetmezlikleri ile sonuçlanmaktadır. $\mathrm{Bu}$ nedenle kan şekerinin olabildiğince normale yakın seviyelerde tutulması çok önemlidir. Dünya sağlık örgütü her yıl yaklaşık 2.9 milyon ölümün diyabetle ilişkisi olduğunu tahmin etmektedir. İnsülin diyabet hastalığının tedavisinde kullanılan ve kan şekerini düşürücü etkiye sahip bir hormondur. Elli bir amino asitten (aa) oluşan polipeptit yapısındaki bu hormon vücutta glukoz dengesini sağlamak için hayati bir öneme sahiptir. Birbirlerine iki disülfit bağıyla birleşmiş olan 21 aa'lik A ve 30 aa'lik B zincirlerinden oluşmaktadır [2]. İnsülin, pankreasın beta hücrelerinden ilk olarak preproinsülin olarak üretilir 84 aa'ten olușur ve daha sonra 33 aa'lik kısmın kimyasal yollarla uzaklaştırılmasıyla aktif insüline dönüştürülür.

Son yıllarda şeker hastalığının görülme sıklığının artması insüline olan ihtiyacı da arttırmıştır. 1920'li yılların başlarından itibaren diyabet, domuz ve sığır pankreasından elde edilen insülinle tedavi edilmekteydi. İnsülinle tedavi gören bir hasta için günlük ortalama doz yaklaşık olarak 40-60 U yani 1.4- $2.1 \mathrm{mg}$ arasındadır. Dünyanın endüstrileşmiş ülkelerinde yılda 130.000 mega U insülin diyabet hastalarını tedavi etmek için kullanılmakta ve her yıl insüline olan ihtiyaç \%3-4 oranında artış göstermektedir [3]. Bir domuz pankreasından yaklaşı $150 \mathrm{mg}$ insülin saflaştırılabilmekte, dolayısıyla mevcut gereksinimleri karşılamak için gerekli olan insülin miktarını pankreatik ekstraksiyondan üretmek oldukça zor olmaktadır. Ayrıca domuz ve sığırdan elde edilen insülin ile insan vücudunun ürettiği insülin arasında yapısal farklılıklar vardır. Domuz insülini, insan insülininden B zincirindeki 30. amino asitin farklı olmasıyla ayrılır. Sığır insülini ise hem $A$ hem de $B$ zincirinde farklılıklar gösterir. A zincirinde insan insülinindeki 8. ve 10. amino asitler ve B zincirindeki 30. amino asitler farklıdır [4]. Bu farklılıklardan dolayı şeker hastalığının tedavisinde bu insülinlerin kullanımı sonrasında antikor gelişme şansı oldukça fazladır. Son 10 yıl içerisinde hayvanlardan elde edilen insülin biyolojik ve kimyasal reaksiyonlarla insan insülinine benzeyecek şekilde değişime uğratılarak yarı sentetik olarak elde edilmeye başlanmıștır. Ancak moleküler biyoloji ve biyoteknoloji alanındaki gelişmelerle birlikte insan vücudunun ürettiği insülinin yapısı ile aynı olacak şekilde genetik mühendisliği teknikleriyle biyosentetik insan insülinleri bakteriler ve mayalar kullanılarak rekombinant DNA teknolojisi ile üretilmeye ve şeker hastaları tarafından yaygın olarak kullanılmaya başlanmıştır.

Rekombinant olarak üretilen ilk ürün insülindir ve 1982 yılında insanlar üzerinde uygulanması Amerikan Gıda ve İlaç Dairesi (U.S.A Food and Drug Administration, FDA) tarafından onaylanmıştır [5, 6]. İlk zamanlarda insülin üretimi iki farklı $E$. coli suşunda A ve B zincirlerinin ayrı ayrı üretilmesi ve taşıyıcı proteinlere kaynaştırılmasına dayanıyordu [7, 8]. Ancak son yıllarda genetik mühendisliği tekniklerinin de gelişmesiyle birlikte $S$. cerevisiae [911], Pichia pastoris [12-15] , Hansenula polymorpha [16, 17], Pichia methanolica [18] gibi alternatif mayalar insülin hormonunun rekombinant olarak üretiminde önemli bir yere sahip olmuşlardır.

Son yllarda özellikle metilotrofik bir maya olan $P$. pastoris rekombinant protein üretiminde yaygın bir şekilde kullanılan ekspresyon sistemi haline gelmiștir. $P$. pastoris, tek hücreli bir mayadır ve bakteriler gibi ucuz üreme ortamlarında hızlı bir şekilde çoğalabilir. Bununla birlikte ökaryotik olduğu için, bakterilerin yapamadıkları ökaryotik proteinler için elzem olan polipeptid katlanması, disülfit bağı oluşumu ve glikozilasyon gibi post-tranlasyonel değişiklikleri yapabilirler [19]. Bu da Pichia ekpresyon sistemini ökaryotik proteinlerin rekombinant üretimi için bakterilere göre daha avantajlı kılar. Bu sistemin yaygın hale gelmesindeki başlıca faktörler; moleküler genetik manipülasyonların kolay uygulanabilir olması, memeli hücreleriyle kıyaslandığında daha ucuz ve basit büyüme ortamına ihtiyaç duyması, yüksek seviyede hem hücre içi hem de hücre dışı protein ekspresyonu yapabilmesi, metanol katabolizmasında ilk enzim olan Alkol Oksidaz I (AOX1) gen promotorunun kontrollü gen ekspresyonu için uygun olması, entegre edilen hedef genin kararlı bir șekilde ekspresyonunun yapılması, diğer mikrobiyal organizmalarla karşılaştırıldığında, fermentör sistemlerinde yüksek hücre yoğunluğuna ulaşabilmesi, ekspresyon sistemine ticari olarak satılan kit şeklinde ulaşılabilir olması olarak sayllabilir $[20,21]$.

Heterolog proteinler P. pastoris ile ya hücre içi olarak ekspres edilirler ya da ortama salgılanırlar. P. pastoris düşük seviyede endojen proteinler salgılar ve kültür ortamı ilave proteinler içermez, çünkü salgılanan heterolog protein ortam içindeki toplam proteinin büyük çoğunluğunu oluşturmaktadır. $\mathrm{Bu}$ yüzden yabancl proteinlerin hücresel proteinlerden ayrılmasında hücre dışına salgılama saflaştırmanın ilk basamağı olarak hizmet eder. Salgılanan yabancı proteinin salgılama yoluna hedeflenmesi için bir sinyal diziye ihtiyaç vardır. Çok farklı salgılama sinyal dizileri bașarıyla kullanılmasına rağmen, sıklıkla $S$. cerevisiae'nın $\alpha$-faktör prepro peptidi salgllama sinyal dizisi olarak başarılı bir şekilde kullanılmaktadır. 
Yukarıda anlatılan bilgiler rekombinant protein üretimi için $P$. pastoris'in ne kadar uygun bir ekspresyon sistemi olduğunu göstermiştir. Diyabet tedavisinde kullanılan insülin hormonunu üretmek için P. pastoris ekspresyon sistemi günümüzde sıcça kullanılmaktadır. Bu çalışmanın amacı, insan insülin hormonu öncülerini P. pastoris mayasında metanol ile indüklenebilen $A O X 1$ promotorunun kontrolü altında üretmektir.

\section{Materyal ve Metot}

\subsection{Kimyasallar ve enzimler}

E. coli XL1-Blue ve $P$. pastoris suşları için besiyeri içerikleri Becton Dickinson (Franklin Lakes, NJ, ABD) firmasından temin edilmiştir. Restriksiyon enzimleri Fermentas (Fermentas, MD, ABD) ve Hot-start KOD DNA polimeraz enzimi Novagen (Darmstadt, Almanya) firmalarından alınmıştır. Çalışmada kullanılan bütün kimyasallar Sigma-Aldrich (MO, ABD'de)'ten satın alınmıştır.

\subsection{Suşlar ve gelişme ortamları}

E. coli XL1-Blue hücreleri plazmitin çoğalması amaciyla, $P$. pastoris $\mathrm{X} 33$ suşu ise rekombinant protein üretiminde konukçu organizma olarak kullanılmıştır. Plazmit içeren E. coli hücreleri $25 \mu \mathrm{g} / \mathrm{ml}$ zeosin antibiyotiği ihtiva eden LB lennox (\%1 tripton, \%0.5 maya özütü ve \%0.5 sodyum klorit) besiyerinde geliştirilmişlerdir. P. pastoris hücreleri ise $\% 1$ maya özütü, $\% 2$ pepton ve $\% 2$ dekstroz içeren YPD sıvı besiyerinde ve \%1.5 agar içeren YPD agar plakalarda geliştirilmişlerdir. YPD agar plakalara transformant hücreleri seçebilmek için $100 \mu \mathrm{g} / \mathrm{ml}$ zeosin antibiyotiği eklenmiştir.

\subsection{Ekspresyon vektörünün oluşturulması}

İnsülin öncülerinin (IP) ekspresyonu için pPICZ $\alpha A$ plazmiti kullanılmıştır. Bu plazmit yüksek derecede regüle edilen $A O X 1$ promotorunu ve $S$. cerevisiae $\alpha$ faktör sekresyon sinyalini içermektedir. 212 bç büyüklügündeki IP kodlayan genin (GeneBank: KC168055.1 ) kimyasal yolla sentezi Genescript (NJ, ABD) firması tarafından yapılmış ve laboratuvarımıza pUC57 plazmidi içerisinde gönderilmiştir. IP genini içeren plazmit ve pPICZ $\alpha$ A plazmiti XhoI ve NotI enzimleriyle kesilerek ligasyon işlemi yapılmıştır. Yeni oluşan plazmit pPICZ $\alpha A$-IP olarak isimlendirilmiştir. Rekombinant plazmitin E. coli XL1Blue hücrelerine transformasyonu yapılmış ve IP geninin klonlanması DNA dizi analizi ile doğrulanmıștır.

\subsection{Lityum asetat yöntemiyle $P$. pastoris hücrelerinin yetenekli (kompotent) hale getirilmesi}

Yetenekli yapılmak istenen $P$. pastoris X33 suşu donmuş kültürden alınarak, $2 \mathrm{ml}$ YPD besiyeri içeren test tüpüne ekilmiş ve $30^{\circ} \mathrm{C}^{\prime}$ de çalkalamalı inkübatörde gece boyu gelişime bırakılmıştır. Ertesi gün, $80 \mathrm{ml}$ YPD besiyerine bașlangıç $\mathrm{OD}_{600}$ değeri 0.1 olacak şekilde gece boyu gelişen kültürden ekilmiş ve 1.3-1.5 OD hücre yoğunluğuna ulaşana kadar $30^{\circ} \mathrm{C}$ 'de çalkalamalı inkübatörde geliştirildikten sonra $+4^{\circ} \mathrm{C}^{\prime}$ de $3000 \mathrm{xg}$ 'de 5 dakika boyunca santrifüjlenerek hücreler hasat edilmişlerdir. Hücre peleti, $8 \mathrm{ml}$ lityum asetat karışımı (100 mM LiAc, $10 \mathrm{mM}$ DTT, $0.6 \mathrm{M}$ Sorbitol, 10 mM Tris-HCl pH 7.4) içinde süspanse edilmiş ve oda sıcaklığında 30 dakika inkübasyona bırakılmıştır. $\quad 4^{\circ} \mathrm{C}^{\prime}$ de $3000 \mathrm{xg}$ hızında 5 dakika santrifüjlenerek tekrar hasat edilen hücreler $1.5 \mathrm{ml}$ buz soğukluğundaki $1 \mathrm{M}$ sorbitol içinde süspanse edilmiş ve $2 \mathrm{ml}$ hacimli santrifüj tüpüne aktarılmıştır. $4^{\circ} \mathrm{C}^{\prime}$ de $3000 \mathrm{xg}$ devirde 5 dakika santrifüjlenerek hasat edilen hücreler $3 \mathrm{kez} 1.5 \mathrm{ml}$ soğuk $1 \mathrm{M}$ sorbitol ile yıkanmış, daha sonra son konsantrasyon $10^{10}$ hücre/ml olacak şekilde buz soğukluğundaki maya resüspansiyon tamponu (1 $\mathrm{M}$ sorbitol, \%20 gliserol) içinde süspanse edilmiş, $80 \mu$ l'lik sıvı bölüntüler halinde $-80^{\circ} \mathrm{C}^{\prime}$ de saklanmıştır.

\subsection{P. pastoris hücrelerine transformasyon}

Ekspresyon plazmiti MssI restriksiyon enzimi ile lineer hale getirilmiş ve elektroporator (Eppendorf, Almanya) yardimiyla elektrokompotent $P$. pastoris X33 hücrelerine transformasyonu $1.5 \mathrm{Kv}$ da yapılmıştır. Transformant hücreler $100 \mu \mathrm{g} / \mathrm{ml}$ zeosin içeren YPD agar plakalara ekilerek $30^{\circ} \mathrm{C}$ 'de 3 gün boyunca inkübasyona bırakılmıștır. YPD plakalarda oluşan tek kolonilerden $3 \mathrm{ml}$ YPD sıvı besiyerine ekim yapılmış ve 2 ml'sinden genomik DNA izolasyonu, 1 ml'sinden ise stok kültür hazırlanarak $-80^{\circ} \mathrm{C}$ 'de saklanmıştır. İzole edilen genomik DNA'larda IP geninin varlığının kontrolü için 5'AOXF: GACTGGTTCCAATTGACAAGC ve 3'AOXR: GCAAATGGCATTCTGACATCC primerleri ile PZR yapılmıştır. PZR reaksiyonu sonunda agaroz jelde yürütülen örneklerde 2000 ve 800 bç uzunluğunda PZR ürünleri beklenmektedir. PZR ile doğrulanan klonlar protein üretiminde kullanılmıştır.

\subsection{Biyoreaktörde insülin hormonu ekspresyonu}

Fermantasyon üç aşamalı fazdan oluşan kesikli besleme (fed-batch) ile gerçekleştirilmiştir. Hücreler $3 \mathrm{ml}$ YPD sıvı besiyerinde $30^{\circ} \mathrm{C}^{\prime} \mathrm{de} 225 \mathrm{rpm}$ 'de gece boyu gelişime bırakılmıştır. $\mathrm{Bu}$ hücreler 10 OD 600 nm'ye ulaştığında $100 \mathrm{ml}$ BMGY besiyerine inokule edilmişlerdir. Batch fazda hücreler $4.35 \mathrm{ml} / \mathrm{L}$ PTM1 (2 g/L CuSO $4.5 \mathrm{H}_{2} \mathrm{O}, 7 \mathrm{~g} / \mathrm{L} \mathrm{ZnCl}_{2}, 0.08 \mathrm{~g} / \mathrm{L} \mathrm{NaI}$, $22 \mathrm{~g} / \mathrm{L} \mathrm{FeSO}_{4} \cdot 7 \mathrm{H}_{2} \mathrm{O}, 3 \mathrm{~g} / \mathrm{L} \mathrm{MnSO}_{4} \cdot \mathrm{H}_{2} \mathrm{O}, 0.2 \mathrm{~g} / \mathrm{L}$ biotin, $0.2 \mathrm{~g} / \mathrm{L} \mathrm{Na}_{2} \mathrm{MoO}_{4} .2 \mathrm{H}_{2} \mathrm{O}, 0.02 \mathrm{~g} / \mathrm{L}$ borik asit, $0.5 \mathrm{~g} / \mathrm{L}$ $\mathrm{CoCl}_{2}, 2 \mathrm{ml} \mathrm{H}_{2} \mathrm{SO}_{4}$ ) içeren 2L temel tuz besiyerine (\%4 gliserol, $26.7 \mathrm{ml} \% 85 \mathrm{H}_{3} \mathrm{PO}_{4}, 0.93 \mathrm{~g} \mathrm{CaSO}_{4}, 18.2 \mathrm{~g}$ $\mathrm{K}_{2} \mathrm{SO}_{4}, 14.9$ g $\mathrm{MgSO}_{4} .7 \mathrm{H}_{2} \mathrm{O}, 4.13 \mathrm{~g} \mathrm{KOH}, 2 \mathrm{ml} \% 5$ köpük kırıcı) ekilmişler ve fermantasyonun ilk aşaması olan gliserol kesikli fazı (batch) gerçekleştirilmiş ve yaklaşık 20 saat sürmüştür. 
Ortamda gliserolün varlığı, çözünmüş oksijen düzeyi takip edilerek izlenmiştir. Gliserolün tükenmesi sonucu, çözünmüş oksijen miktarında ani artış gözlenmekte ve böylece kesikli faz sona ermektedir. $\mathrm{Bu}$ aşamadan sonra fermantasyonun ikinci aşaması olan gliserol besleme fazı (fed-batch) başlatılmıştır. $\mathrm{Bu}$ fazda, 2 saat boyunca \%40 gliserol kullanılarak $16.5 \mathrm{ml} / \mathrm{L} . \mathrm{sa}$ olacak şekilde gliserol beslemesi yapılmıştır. $\mathrm{Bu}$ sürenin sonunda, ortama $A O X 1$ promotoru indüksiyonu için $2 \mathrm{ml} / \mathrm{L}$ metanol ilave edilmiş ve gliserol besleme hızı $0 \mathrm{ml} /$ L.sa düzeyine 3 saatlik süre içinde lineer olarak düşürülmüştür. Ortamdaki karbon kaynaklarının tükenmesi ile çözünmüş oksijen miktarında ani artış gözlenmiş ve fermantasyonun 3. aşaması olan indüksiyon fazına geçilmiştir. Bu fazda 32 saat boyunca $\% 100$ metanol (12 ml/L PTM1 tuzu içeren) ile besleme yapılmıştır. İşlem boyunca; sicaklık $30^{\circ} \mathrm{C}, \mathrm{pH}$ değeri 5.5, karıştırma hızı $1000 \mathrm{rpm}$ ve hava beslemesi $1.0 \mathrm{vvm}$ olacak şekilde sabit tutulmuştur. Çözünmüş oksijen miktarı ise, gerektiğinde saf oksijen eklenerek, \%20 olacak șekilde kontrol edilmiștir. Fermantasyon süresi boyunca belirli aralıklarla örnek alınmış, santrifüj edilerek süpernatan kısımları elde edilmiş ve SDS-PAGE ve ELISA analizleri için $-20^{\circ} \mathrm{C}$ 'de işlem yapılana kadar muhafaza edilmiştir.

\subsection{Histidin etiketli proteinin saflaştırılması}

5 L hacimli fermentörde üretilen insan insülin hormonu öncüleri C-terminal ucunda 6 adet histidinden oluşan bir kuyruk taşımaktadır. Bu kuyruk sayesinde üretilen protein Ni-NTA resin kullanılarak saflaştırılabilmektedir. Metanol ile indüksiyon fazının 32. saatinde alınan protein örneği 6000 g'de 5 dakika santrifüj edilip $0.45 \mu \mathrm{m}$ filtreden geçirildikten sonra eșit miktarda örnek ve $10 \mathrm{mM}$ imidazol içeren equilibration tamponu karıştırılarak dengeye getirilmiştir. $1 \mathrm{ml} \mathrm{Ni-NTA}$ resin $5 \mathrm{ml}$ dengeye getirilmiş süpernatan örneğine eklenerek 30 dakika boyunca histidin etiketli proteinin resine tutunması sağlanmıştır. Resinle birlikte süpernatan boş bir kolona yüklenmiş ve flow-through bir tüpün içine toplanmıştır. Daha sonra kolon iki kez $25 \mathrm{mM}$ imidazol içeren yıkama tamponu ile yıkanmış, 1 . ve 2 . yıkamadan elde edilen örnekler tüpler içine toplanmıştır. Sonra $200 \mathrm{mM}$ imidazol içeren elüsyon tamponu ile resinden geri alınmıştır. Tüm bu işlemler sırasında toplanan yıkama ve elüsyon fraksiyonları SDS - PAGE analizi ile kontrol edilmiştir.

\subsection{SDS-PAGE analizi}

Toplanan süpernatan örnekleri $2 \mathrm{X}$ Tris ve gliserolden oluşan Trisin örnek tamponu ve 1M DTT ile karıştırılarak $70^{\circ} \mathrm{C}^{\prime}$ de 10 dakika bekletilerek jele yüklemeye hazır hale getirilmişlerdir. Hazırlanan örnekler standart protokole göre \%10'luk Tris-tricine SDS-PAGE jelinde ayrılmışlardır [22]. Elektroforez işleminden sonra jel coomasie brillant blue R250 (Thermo Fisher Scientific, MA, ABD) kullanilarak 1 saat boyunca orbital çalkalayıcıda boyanmıştır.
Boyanan jel daha sonra 1 saat boyunca destaining solüsyonuna alınarak fazla boyanın uzaklaștırılması sağlanmıș ve 15 dakikada saf su ile yıkandıktan sonra Odyssey Infrared Imaging System (LI-COR, Lincoln, $\mathrm{NE}, \mathrm{ABD}$ ) ile görüntülenmiştir.

\subsection{ELISA analizi}

Üretilen insülin hormonunun miktarı Human insülin ELISA Kit (Sigma-Aldrich, MO, ABD) protokolüne uygun bir şekilde belirlenmiştir. 96 kuyucuklu plakada hazırlanan reaksiyonlar ELISA plaka okuyucuda $450 \mathrm{~nm}$ 'de okunmuştur.

\section{Bulgular}

\subsection{Protein üretimi için klon seçimi}

pPICZ $\alpha$ A-IP ekspresyon plazmitinin (Şekil 1) $P$. pastoris X33 hücrelerine transformasyonu yapıldıktan sonra YPD agar plakalarda gelişen transformant hücrelerden genomik DNA izolasyonu yapılmış ve kromozomlara IP geninin girip girmediğini kontrol etmek için klonların PZR reaksiyonunda kalıp olarak kullanılmıştır.

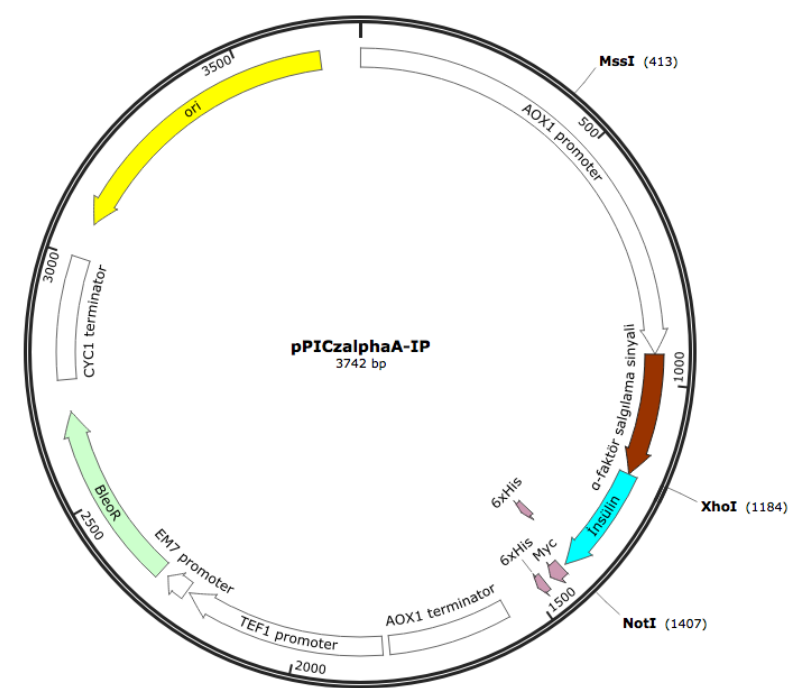

Şekil 1. Olușturulan pPICZ $\alpha A-I P$ ekspresyon vektörünün şematik gösterimi

PZR reaksiyonu sonucunda 2000 bç ve 800 bç uzunluğunda beklenen fragmentler elde edilmiş (Şekil 2) ve IP geninin X33 hücrelerine entegre olduğu doğrulanmiștır. $\mathrm{Bu}$ doğrulama işlemi sonrasında 1 numaralı klon ile protein ekspresyonu çalışmalarına devam edilmiştir.

\subsection{L hacimli biyoreaktörde protein üretimi}

Rekombinant insan insülin hormonu öncülerinin ekspresyonu $P$. pastoris'te metanol ile indüklenebilen güçlü $A O X 1$ promotorunun kontrolünde yapılmıştır. Hücre içinde üretilen proteinin hücre dişına salgılanması için $\alpha$-faktör salgılama sinyali olarak kullanılmıştır. Biyoreaktörde 3 aşamada gerçekleştirilen fermantasyonun ilk iki aşamasında 


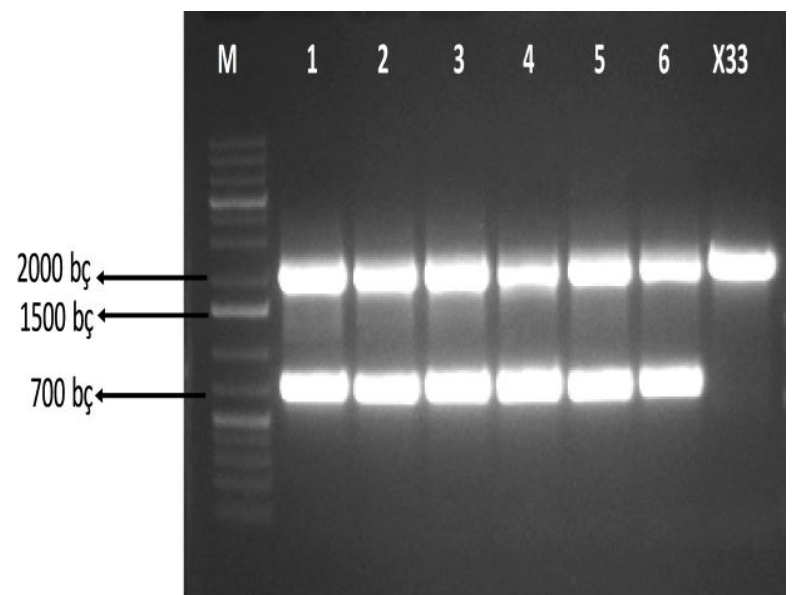

Şekil 2. PZR reaksiyonu agaroz jel görüntüsü. Transformasyon sonrası elde edilen kolonilerin IP genini içerip içermediklerinin PZR reaksiyonu ile kontrolü. M: $1 \mathrm{~kb}$ DNA ladder, 1-6: İzole edilen klon numaraları, X33: IP genini içermeyen kontrol

hücreler geliştirilmiş ve üçüncü aşama olan metanol ile indüksiyon fazında protein üretimi gerçekleşmiş ve indüksiyon fazı 32 saatte tamamlanmıştır. Bu süre içerisinde belirli aralıklarla örnek alınmış ve bu örneklerle SDS-PAGE analizi yapılmıştır (Şekil 3). Olgun insülin proteini $5.8 \mathrm{kDa}$ moleküler ağırlı̆̆a sahip iken bu çalışmada üretilen insülin öncüleri proteini sonuna histidin kuyruğununda eklenmesiyle 7.8 kDa moleküler ağırlığına ulaşmıştır. Şekil 3.'de de görüldügü gibi 4. saatten 32. saate doğru bakıldığında $7.8 \mathrm{kDa}$ boyutunda protein bandının arttığı ve klonun IP ürettiği gözlenmiştir. Yapılan ELISA analizi ile üretilen proteinin miktarı hesaplanmış ve fermantasyon sonunda $7.5 \mathrm{mg} / \mathrm{L}$ protein üretildiği bulunmuştur.

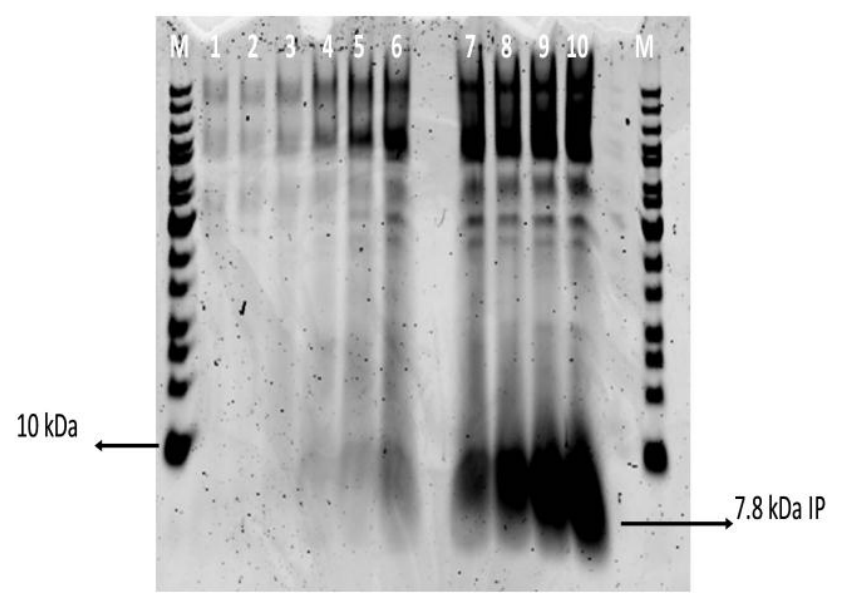

Şekil 3. Fermentör örneklerinin SDS-PAGE analizi görüntüsü. M: Protein ladder, 1: Batch faz sonundaki kültür süpernatanı, 2: Metanol fed-batch faz 0. saat örneği, 3-10: sirasiyla 4., 8., 12., 16., 20., 24., 28. ve 32. saat süpernatan örnekleri

\section{3. İnsülin öncülerinin saflaştırılması}

32. saat sonunda fermantasyon tamamlanmış ve elde edilen süpernatan örneğine histidin saflaştırılması yapılmıştır (Şekil 4).

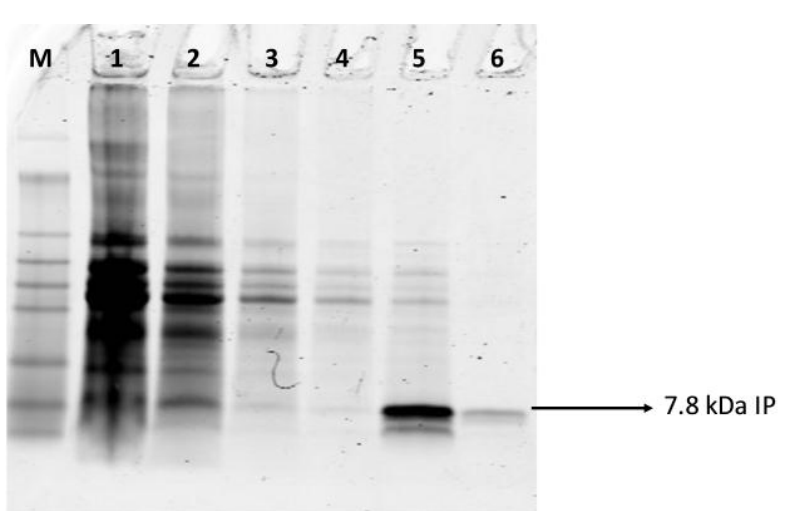

Şekil 4. His-taq saflaştırması SDS-PAGE analizi görüntüsü. 32. saat fermentör örneğine Ni-NTA kolon kullanılarak histaq saflaştırılması yapılmıştır. M: markır, 1: 32. saat örneği, 2: Flow-through, 3: $25 \mathrm{mM}$ imidazol ile 1. ylkama, 4: $25 \mathrm{mM}$ imidazol ile 2. yıkama, 5: $200 \mathrm{mM}$ imidazol ile 1. elüsyon, 6: $200 \mathrm{mM}$ imidazol ile 2. Elüsyon

Ni-NTA resine bağlanan histidin etiketli proteinin $200 \mathrm{mM}$ imidazol ile elüsyonu yapılmış ve $7.8 \mathrm{kDa}$ büyüklügü̈ndeki IP proteini elüsyon 1 ve elüsyon 2 olmak üzere iki fraksiyonda toplanmıştır. Şekil 4.'de de görüldüğü gibi üretilen IP'nin neredeyse tamamı birinci elüsyonda elde edilmiştir. Saflaştırılan proteinin miktarı ELISA analizi ile hesaplanarak 1.5 $\mathrm{mg} / \mathrm{L}$ olarak bulunmuștur.

\section{Tartışma ve Sonuç}

Dünyada ve ülkemizde diyabet hastalığının artmasıyla birlikte insülin hormonuna olan ihtiyaçta artmıştır. İnsülinin direkt olarak hayvanların pankreasından saflaştırılarak elde edilmesi etik açıdan bazı sakıncaları doğuracağı gibi elde edilen ürün miktarının az olması da insülin eldesi için uygun bir yöntem olmadığını göstermiştir. Genetik mühendisliğindeki gelişmelerle birlikte rekombinant protein üretimi insülin gibi hayati öneme sahip farmasötiklerin endüstriyel olarak üretilmesine imkan sağlamıştır.

$\mathrm{Bu}$ çalışma kapsamında insan insülin hormonu öncülerinin (IP) P. pastoris ekspresyon sisteminde AOX1 promotoru kontrolü altında $\alpha$-faktör salgılama sinyali kullanılarak hücre dışı üretimi sağlanmıştır. 5 L'lik biyoreaktör kullanılarak yapılan fermantasyon sonunda $7.5 \mathrm{mg} / \mathrm{L}$ IP proteini üretilmiştir. Üretilen protein, kültür süpernatanı kullanılarak saflaştırıldığında $1.5 \mathrm{mg} / \mathrm{L}$ saf IP elde edilmiştir. Saflaştırma esnasında protein miktarında kayıp söz konusu olmuştur.

Literatürde daha önce yapılan çalışmalara bakıldığında insülin öncüleri rekombinant olarak üretilip daha sonra aktif insülin formuna dönüştürülmektedir. Kjeldsen vd. (1999)'nin yaptığı çalışmada $P$. pastoris ve $S$. cerevisiae mayaları kullanılarak insülin ekspresyonu yapılmış ve bu iki maya birbirleriyle kıyaslanmıştır [12]. S. cerevisiae'da IP salgılanması için sentetik prepro-lider dizileri 
geliștirilmiş ve bu dizilerin $P$. pastoris'te de IP salgılanmasını hızlandırdığı kanıtlanmıştır. Füzyon proteininde çeşitli ara peptitler kullanılmış ve bu peptitlerin kullanılmasinın $P$. pastoris'te IP'nin fermantasyon ürün verimini arttırdığı yine bu çalışmayla gösterilmiştir. En yüksek verim "Glu Glu Ala Glu Ala Glu Ala Glu Pro Lys (EEAEAEAEPK)” ara peptidinin $\alpha$-faktörü sinyal dizisiyle birlikte oluşturduğu ekspresyon vektöründe elde edilmiştir. $P$. pastoris'in IP salgılanması için $S$. cerevisiae ile eşit ya da daha iyi kapasiteye sahip olduğu Kjeldsen vd. (1999) tarafından ifade edilmiştir [12]. Yine başka bir çalışmada IP, yüksek kopya numarasına sahip transformantlardan, başlıca tuz ve metanolden oluşan basit kültür ortamı kullanılarak yüksek yoğunluklu fermantasyonla $1.5 \mathrm{~g} / \mathrm{L}$ ekspresyon seviyesinde elde edilmiștir [13]. P. pastoris'in Mut ${ }^{\mathrm{s}}$ (methanol utilization slow) suşunda mini-proinsülin (MPI) üretmeye çalışılmış ve MPI salgılanmasının indüksiyon fazı boyunca populasyonun gelişimiyle olan ilgisi incelendiğinde, elde ettikleri MPI miktarı 1.5 g/L'yi geçememiştir [14]. Buna ek olarak MPI'in toplam miktarı ile toplam biyokütle ilişkilendirildiğinde, ilgilenilen ürünün metanol fazında büyümeyle ilgisi olduğu görülmüştür. Aynı ekibin yaptığı başka bir çalışmada sıcaklık, pH ve farklı nitrojen kaynaklarının yine aynı suşda MPI üretimine olan etkisine bakılmıştır. Kültivasyon $\mathrm{pH}$ 'sı $5.1^{\prime}$ den $6.3^{\prime}$ e yükseltilmiş, sicaklık $28^{\circ} \mathrm{C}$ 'den $22^{\circ} \mathrm{C}^{\prime}$ ye düşürülmüș ve periyodik olarak amonyum sülfat ve EDTA kültür ortamına eklenerek 160 saatlik gelişme sonrasında MPI salgılanmasının $0.3 \mathrm{~g} / \mathrm{L}$ seviyesine ulaştığı görülmüştür [23]. P. pastoris'te IP üretimi için yine Ala-Ala-Lys bağlayıcı peptiti ve $\alpha$-faktörü sinyal dizisi kullanılarak ekspresyon plazmidi pPIC9'da 16 litrelik fermentörde $3.6 \mathrm{~g} / \mathrm{L}$ IP üretilmiş ve üretilen IP aktif insüline dönüştürüldüğünde verimin $\% 70$ seviyesinde olduğu belirtilmiştir [24]. Gurramkonda vd. (2010) tarafindan yapılan çalışmada ise $\alpha$-faktör sinyal dizisi liderliğinde AAK bağlayıcı peptidi ve EEAEAEAEPK ara peptidi kullanılarak ekspresyon vektörü dizayn edilmiş ve daha sonrasında kesikli gliserol ve sabit miktarda metanolden oluşan yarı kesikli beslemeli iki fazlı kültivasyon işlemi uygulanmıştır [15]. Bu yaklaşım IP üretimini 2 kat arttırmış ve saflaştırılan IP insan insülinine dönüştürüldükten sonra 1 litre sıvı kültürde yaklaşık $1.5 \mathrm{~g}$ ve \%99 saflıkta rekombinant insan insülini elde edilmiştir. $P$. pastoris'te rekombinant insan insülini öncülerinin AOX1 promotoru altında üretimiyle ilgili yapılan bir başka çalışmada ise fermantasyon sonrasında 200-400 mg/L IP elde edildiği rapor edilmiştir [25]. Aynı grubun başka bir çalışmasında ise bir insülin analoğu olan aspart insülin $P$. pastoris'te $A O X 1$ promotoru altında üretilmiş ve sonuçta $400 \mathrm{mg} / \mathrm{L}$ aspart insülin öncüsü elde edildiği ifade edilmiştir [26].

Sonuç olarak, yapılan bu çalışma sonunda insülin hormonu öncüleri üreten bir suş elde edilmiştir. Ancak, bu çalışmada elde edilen protein miktarının literatürdeki diğer çalışmalarla kıyaslandığında daha az olduğu görülmüştür. Bu çalışmada kullanılan füzyon proteini saflaștırma işleminde kolaylık sağlaması açısından 6X Histidin etiketi taşıyacak şekilde dizayn edilmiştir. Literatürde bulunan diğer çalışmalarda, üretilen protein histidin etiketi taşımamaktadır. Proteinin sonuna takılan histidin etiketinin, hücre dıșına salgılanan protein miktarını azaltıcı yönde bir etkisinin olma ihtimali bulunmaktadır. Ayrıca üretimde kullanılan fermantasyon şartları, diğer çalışmalarla klyaslandığında farklılıklar göstermektedir. Rekombinant protein üretiminde fermentörde üretim esnasında karıștırma hızı, hava, besleme profili, çözünmüş oksijen konsantrasyonu, sicaklık ve pH değerlerinin üretilecek her bir proteinde farklı optimum koşullar gerektirdiği bilinmektedir. Dolayısıyla fermantasyon koşullarında yapılacak optimizasyon çalışmalarıyla üretilen protein miktarı arttırllabilecektir. Bütün bunlarla birlikte; üretilen proteinin miktar tayininde ELISA analizi kullanılmış ancak literatürdeki diğer yayınlarda miktar tayini için HPLC analizi yapılmıştır. Dolayısıyla protein miktarlarındaki farkın bir diğer sebebinin ise, kullanılan metotlarının farklılığından kaynaklanmış olma ihtimali bulunmaktadır.

\section{Teşekkür}

Bu çalışma Türkiye Bilimsel ve Teknolojik Araştırma Kurumu tarafından Kariyer Geliştirme Programı kapsamında $114 Z 164$ proje numarasıly desteklenmiştir.

\section{Kaynakça}

[1] Brownlee, M. 2001. Biochemsitry and molecular cell biology of diabetic complications. Nature, 414, 813-820.

[2] Ahmad, B. 2004. Pharmacology of insülin. Br J Diabetes Vasc Dis, 4, 10-14.

[3] Kjeldsen, T. 2000. Yeast secretory expression of insulin precursors. Appl Microbiol Biotechnol, 54, 277-286.

[4] Heinemann, L., Richter, B. 1993. Clinical pharmacology of human insulin. Diabetes Care, 16(3), 90-100.

[5] Walsh, G. Therapeutic insulins and their largescale manufacture. Appl Microbiol Biotechnol, 67, 151-159.

[6] Ferrer-Miralles, N., Domingo-Espin, J., Corchero, J.L., Vazquez, E., Villaverde, A. 2009. Microbial factories for recombinant pharmaceuticals. Microb Cell Fact, 8, 17.

[7] Goeddel, D.V., Kleid, D.G., Bolivar, F., Heyneker, H.L., Yansura, D.G., Crea, R., Hirose, T., Kraszewski, A., Itakura, K., Riggs, A.D. 1979. Expression in Escherichia coli of chemically 
synthesized genes for human insulin, Proc Natl Acad Sci USA, 76, 106-110.

[8] Schmidt, M., Babu, K.R., Khanna, N., Marten, S., Rinas, U. 1999. Temperature-induced production of recombinant human insulin in high-cell density cultures of recombinant Escherichia coli. J Biotechnol, 68, 71-83.

[9] Thim, L., Hansen, M.T., Norris, K., Hoegh, I., Boel, E., Forstrom, J., Ammerer, G., Fiil, N.P. 1986. Secretion and processing of insulin precursors in yeast. Proc Natl Acad Sci USA, 83, 6766-6770.

[10] Kjeldsen, T., Brandt, J., Andersen, A.S., EgelMitani, M., Hach, M., Frost-Petterson, A., Vad, K. 1996. A removable spacer peptide in an 0 factor-leader/insulin precursor fusion protein improves processing and concomitant yield of the insulin precursor in Saccharomyces cerevisiae. Gene, 170, 107-112.

[11] Kjeldsen, T., Frost-Petterson, A., Hach, M., Diers, I., Havelund, S., Hansen, P.H., Andersen, A.S. 1997. Synthetic leaders with potential bip binding mediate high-yield secretion of correctly folded insulin precursors from Saccharomyces cerevisiae. Protein Expression And Purification. 9, 331-336.

[12] Kjeldsen, T., Frost-Petterson, A., Hach, M. 1999. Secretory expression and characterization of insulin in Pichia pastoris. Biotechnol Appl Biochem. 29, 79-86.

[13] Wang, Y., Liang, Z.H., Zhang, Y.S., Yao, S.Y., Xu, Y.G., Tang, Y.H., Zhu, S.Q., Cui, D.F., Feng, Y.M. 2001. Human insulin from a precursor overexpressed in the methylotrophic yeast Pichia pastoris and a simple procedure for purifying the expression product. Biotechnol Bioeng. 73, 74-79.

[14] Pais, J.M., Varas, L., Valde's, J., Cabello, C., Rodriguez, L., Mansur, M. 2003. Modeling of mini-proinsulin production in Pichia pastoris using the AOX promoter. Biotechnol Lett. 25, 251-255.

[15] Gurramkonda, C., Polez, S., Skoko, N., Adnan, A., Gabel, T., Chugh, D., Swaminathan, S., Khanna, N., Tisminetzky, S., Rinas, U. 2010. Application of simple fed-batch technique to high-level secretory production of insulin precursor using Pichia pastoris with subsequent purification and conversion to human insülin. Microbial Cell Factories, 9(31), 1-11.

[16] Weydemann, U., Keup, P., Piontek, M., Strasser, A.W.M., Schweden, J., Gellissen, G., Janowicz, Z.A.
1995. High-level secretion hirudin by Hansenula polymorpha-authentic processing of three different preprohirudins. Appl Microbiol Biotechnol, 44, 377-385.

[17] Gellissen, G., Melber, K. 1996. Methylotrophic yeast Hansenula polymorpha as production organism for recombinant pharmaceuticals. Arzneimittelforschung, 46, 943-948.

[18] Raymond, C.K., Bukowski, T., Holderman, S.D., Ching, A.F.T., Vanaja, E., Stamm, M.R. 1998. Development of the Methylotrophic Yeast Pichia methanolica for the Expression of the 65 Kilodalton Isoform of Human Glutamate Decarboxylase. Yeast, 14, 11-23.

[19] Hagenson, M..J. 1991. Production of recombinant proteins in the methylotrophic yeast Pichia pastoris. Bioprocess Technol, 12, 193-212.

[20] Cregg, J.M., Vedvick, T.S., Raschke, W.C. 1993. Recent advances in the expression of foreign genes in Pichia pastoris. Bio/Technol, 11, 905910.

[21] Cereghino, J.L., Cregg, J.M. 2000. Heterologous protein expression in the methylotrophic yeast Pichia pastoris. FEMS Microbiology Reviews, 24, 45-66.

[22] Schagger, H., Von Jagow, G. 1987. Tricine-sodium dodecyl sulfate-polyacrylamide gel electrophoresis for the separation of proteins in the range from 1 to $100 \mathrm{kDa}$. Analytical Biocehmistry, 166(2); 368-379.

[23] Pais-Chanfrau, J.M., Garcia, Y., Licor, L., Besada, V., Castellanos-Serra, L., Cabello, C.I., Hernandez, L., Mansur, M., Plana, L., Hidalgo, A., Tambara, Y., Abrahantes-Perez, M., Toro, Y., Valdes, J., Martinez, E. 2004. Improving the expression of mini-proinsulin in Pichia pastoris. Biotechnology Letters, 26, 1269-1272.

[24] Xie, T., Liu, Q., Xie, F., Liu, H., Zhang, Y. 2008. Secretory expression of insulin precursor in Pichia pastoris and simple procedure for producing recombinant human insulin. Preparative Biochemistry \& Biotechnology, 38, 308-317.

[25] Annibali, N. 2006. Expression of a human insulin precursor in P. Pastoris. United States Patent, Patent No: US 7,091,032 B2.

[26] Annibali, N., Goin, M., Trejo, G., Carrizo, F., Baruque, D., Morales, A. 2011. Process for obtaining aspart insulin using a pichia pastoris yeast strain,United States Patent Application Publication, Pub No: US/2011/0117600. 